\title{
PENERIMAAN DIRI WARGA BINAAN LAPAS WANITA KLS IIA TANGERANG PASCA KEGIATAN RUTIN KOMUNIKASI DA'WAH TIM RELAWAN DA'WAH MUSLIMAT DDII
}

\author{
Dr. Santa Lorita Simamora, M.Si \\ Dicky Andika S.Sos, M.Si
}

santa.lorita@mercubuana.ac.id

Universitas Mercu Buana

\author{
Muslimah Hannan \\ Ida Sofie Haryanti
}

STID-Muhammad Natsir

\begin{abstract}
The purpose of this study was to determine the self-acceptance of female assisted residents in Class IIA Lapas after following a routine study of Islam called the assimilation program by the Da'wah Muslimat Center Volunteer Team of the Indonesian Islamic Da'wah Council since 2015.

This qualitative research approach uses a case study method that seeks to describe in detail and comprehensively the psychological condition of female assisted residents in their acceptance during their period of detention and to be given Islamic religious enlightenment regularly by the Da'wah Muslimat Center Volunteer Team of the Indonesian Da'wah Islamiyah Council. . The informants of this study were around 12 female prisoners in the Class IIA Correctional Institution in Tangerang, Banten who are currently participating in the assimilation program. of the sentence.

The number of research informants was taken using purposive sampling technique. Collecting data using observation and indepth interviews with research informants as well as conducting documentation studies through various documents related to the research theme. The results of data collection were analyzed using the qualitative data analysis model from Milles and Huberman. The results showed that generally the assisted residents had self-acceptance after participating in the assimilation program, although for different reasons.
\end{abstract}

Keywords: Self-acceptance, Persuasive Communication, Assisted Citizens, Islamic Studies.

\begin{abstract}
ABSTRAK
Tujuan penelitian ini untuk mengetahui penerimaan diri warga binaan wanita di Lapas Klas IIA pasca mengikuti kajian rutin Agama Islam yang disebut program asimilasi oleh tim Relawan Da'wah Muslimat Center Dewan Da’wah Islamiyah Indonesia sejak 2015.

Pendekatan penelitian kualitatif ini menggunakan metode studi kasus yang ingin menggambarkan secara detil dan komprehensif tentang kondisi psikologis diri warga binaan wanita dalam penerimaan dirinya selama menjalani masa tahanan dan diberikan pencerahan agama Islam secara rutin oleh tim Relawan Da'wah Muslimat Center Dewan Da'wah Islamiyah Indonesia. Informan penelitian ini adalah sekitar 12 Warga Binaan Pemasyarakatan Wanita di Lembaga Pemasyarakatan Klas IIA di Tangerang, Banten yang
\end{abstract}


sedang mengikuti program asimilasi, mayoritas kasus warga binaan wanita terjerat kasus penyalahgunaan narkotika, baik sebagai pengguna ataupun pengedar, dan telah menjalani masa hukuman minimal lima puluh persen dari masa hukuman.

Jumlah informan penelitian diambil dengan menggunakan teknik purposive sampling. Pengumpulan data menggunakan observasi, dan wawancara mendalam kepada informan penelitian serta melakukan studi dokumentasi melalui berbagai dokumen terkait tema penelitian. Hasil pengumpulan data dianalisis dengan model analisis data kualitatif dari Milles dan Huberman. Hasil penelitian menunjukkan bahwa umumnya warga binaan memiliki penerimaan diri setelah mengikuti program asimilasi meskipun dengan alasan yang berbeda-beda.

\section{Kata Kunci: Penerimaan Diri, Komunikasi Persuasif, Warga Binaan, Kajian Ilmu Agama Islam}

\section{PENDAHULUAN}

Hampir setiap kota besar di Indonesia ditemui kasus penyalahgunaan narkoba yang dilakukan oleh wanita. Penyalahgunaan narkoba secara hukum merupakan kriminalitas yang menyalahi ketentuan yang termasuk kedalam kitab undang- undang hukum pidana (KUHP) baik sebagai pengedar maupun pemakai akan dijatuhi hukuman penjara beberapa tahun atau seumur hidup bahkan bisa dihukum mati seperti yang terjadi pada Rani Adriani dari Cianjur (2000) karena kedapatan membawa heroin sebanyak 3500 gram..

Faktor kondisi ekonomi, mulai dari kemiskinan, gaya hidup komsumtif, serta kecanduan narkoba juga seks bebas membuat wanita tergelincir menjadi pengguna dan pengedar barang haram tersebut. Dorongan sosial yang disebutkan dalam kalimat sebelumnyamenjadi beberapa penyebab wanita terlibat penyalahgunaan narkotika. Seperti ujaran salah satu penghuni Lembaga Pemasyarakatan Wanita Kelas IIA Tangerang, sebut saja Tati, bahwa sulitnya keadaan ekonomi dan mencari pekerjaan, membuat yang bersangkutan nekad mengambil jalan pintas menjadi kurir barang terlarang agar mudah memperoleh uang. Kisah ini merupakan salah contoh penyebab wanita menjalani masa tahanan dalam periode tertentu di penjara akibat terlibat penyalahgunaan narkotika.

Hasil penelitian Anastasia (2012), menyatakan bahwa terlibatnya wanita dalam aktivitas kriminal menunjukkan terdapat hubungan antara sejarah hidup para wanita dengan pelanggaran hukum yang telah mereka lakukan. Berbagai faktor membuat mereka menjadi salah satu pelaku dalam tindak penyalahgunaan narkotika. Menurut Humas Kementerian Pemberdayaan Perempuan dan Perlindungan Anak (KPP \& PA) prevalensi warga negara Indonesia yang terlibat penyalahgunaan narkoba di 2010 diperkirakan sebesar 12 persen. Atau sekitar 30 juta orang Indonesia terlibat penyalahgunaan dan peredaran narkoba di Indonesia. Data Badan Narkotika Nasional $[\mathrm{BNN}]$ menyebutkan 0,0026 persen di antaranya adalah perempuan. Artinya terdapat 
(https://www.kemenpppa.go.id/index.php/page/read/30/334/bahava-perempuan-indonesiarawan-jadi-pengedar-narkotika, edisi 23 ebruari 2016).

Keterlibatan wanita dalam penyalahgunaan narkoba beraneka ragam, mulai menjadi pemasok, pengedar, perantara, hingga menjadi pengguna. Jumlah wanita yang terlibat tiap tahun meningkat, 2013 tercatat di Badan Narkotika Nasional (BNN) 4.297 perempuan terlibat peredaran gelap narkotika di Indonesia. Kaum perempuan kebanyakan terlibat peredaran gelap narkotika jenis ganja, heroin, kokain, ekstasi, dan sabu. Label perempuan di Indonesia yang dinilai naif, tidak pikir panjang, dan mudah dimanfaatkan membuat para sindikat merekrut para perempuan, sehingga tidak heran dengan kondisi tersebut jumlah perempuan tercatat makin banyak terlibat penyalahgunaan narkotika. Meskipun kasus narkoba kian tahun menurun di Indonesia, seperti di 2018 mengalami penenurunan menjadi 990 kasus Pusdatin BNN 2018), namun 60\% penghuni Lapas Wanita berlatar belakang kasus penyalahgunaan narkoba.

Menurut Kartono (2009), warga binaan pemasyarakatan yang telah lama terisolasi dalam penjara menyebabkan hilangnya partisipasi sosial. Warga binaan pemasyarakatan yang dulunya memiliki sifat baik dan rasa empati terhadap lingkungan, setelah masuk penjara tidak menjadi sadar akan kesalahan justru keluar tanpa adanya perbaikan sifat yang lebih baik dari sebelumnya. Bahkan, ada yang mengulangi tindak kejahatan untuk kedua kalinya. Para warga binaan pemasyarakatan semakin tidak memiliki rasa empati dan kesadaran dalam lingkungan sosial akan membuat kemampuan mereka juga ikut menghilang atau tidak berkembang. Selain itu ada juga warga binaan pemasyarakatan yang setelah mendapatkan vonis dari pengadilan kemudian kondisi kejiwaannya menurun dan membuat rasa kepedulian terhadap lingkungannya menjadi tertutup.Warga binaan pemasyarakatan merasa cemas apabila mendapatkan penolakan dari lingkungan tempat tinggalnya.

Fahruliana (2011) berpendapat bahwa tingkat kecemasan semakin bertambah akan dirasakan oleh warga binaan pemasyarakatan menjelang masa pembebasan. Hal ini karena adanya sikap masyarakat yang sulit menerima kembali kedatangan warga binaan pemasyarakatan ke dalam kehidupan dan lingkungan sekitarnya.Warga binaan pemasyarakatan mengalami perasaan yang tidak diinginkan seperti perasaan tertekan, malu kepada masyarakat, rasa takut tidak dapat lagi diterima oleh lingkungan sosial, dan sulitnya mendapat pekerjaan. Sehingga membuat timbulnya kecemasan dan rasa rendah diri saat harus berhadapan dengan orang-orang di lingkungan sosialnya kelak. 
Terkait masalah tersebut, Lembaga Pemasyarakatan membuat program pembinaan dengan pendekatan agama. Program pembinaan warga binaan dengan pendekatan agama membutuhkan tenaga-tenaga ahli yang paham agama.Oleh karena itu Lapas membuka diri kepada pihak-pihak yang dapat membantu. Lapas Kelas IIA Tangerang menggandeng pihakpihak yang peduli, salah satunya adalah Dewan Da'wah Islamiyah Indonesia yang memiliki visi "Terwujudnya tatanan kehidupan masyarakat Indonesia yang Islami dalam NKRI yang kuat dan sejahtera” (Pasal 4 AD/ART Pengurus Dewan Da’wah Islamiyah Indonesia ).

Kerja sama Dewan Da’wah Islamiyah Indonesia dan Lapas Wanita Kelas IIA Tangerang melalui kegiatan peduli masyarakat Muslimat Dewan Da'wah Islamiyah Indonesia diwakili oleh tim relawan Muslimat yang terdiri dari para anggota Muslimat Dewan Da'wah. Kegiatan pencerahan dilakukan rutin tiga kali dalam sepekan sejak 2015 oleh anggota tim relawan secara bergantian sesuai jadual yang telah disepakati. Penyampaian pesan agama Islam dengan metode komunikasi da'wah secara persuasif diharapkan dapat membentuk mental dan pengetahuan agama yang baik sehingga warga binaan memiliki ahlak baik ketika kembali kepada kehidupan masyarakat. Komunikasi da'wah yang dilakukan bersifat persuasif bahkan bisa disebut bersifat komunikasi hati, secara intensif pesan-pesan da'wah disampaikan melalui program asimilasi yang pesertanya mendekati masa akhir hukuman tahanan.

Melalui program asimilasi para warga binaan dibimbing dapat menyiapkan diri menghadapi berbagai kondisi dan respon masyarakat bila sudah bebas kelak. Berbagai pengetahuan agama diajarkan prioritasnya ketauhidan yaitu mengenal Sang Pencipta sehingga para warga binaan bisa lebih menjaga perilaku menjadi insan yang lebih baik di mata Allah Rabb semesta alam.

Berdasarkan uraian di atas penulis tertarik melakukan penelitian tentang bagaimana penerimaan diri warga binaan wanita di Lembaga Pemasyarakatan Wanita Kelas IIA Tangerang pasca mengikuti pencerahan rohani secara rutin dan intensif dari tim relawan da'wah Muslimat Dewan Da'wah Islamiyah Indonesia.

Lembaga Pemasyarakatan Wanita Kelas IIA Tangerang menjadi pilihan penulis sebagai tempat penelitian karena Lapas tersebut telah menerapkan metode komunikasi persuasif dan prinsip melayani kepada sekitar 350 warga binaan wanita dengan umumnya terlibat kasus penyalahgunaan narkotika. 
Warga binaan atau napi wanita membutuhkan pembinaan agar mereka bisa memiliki ahlak baik ketika kembali ke masyarakat. Namun pembinaan kepada para warga binaan atau napi wanita di lapas lebih khusus membutuhkan pembinaan dengan pendekatan agama dan komunikasi persuasif agar hati nurani para warga binaan wanita tersentuh oleh nilai-nilai ahlakulkarimah yang diajarkan Rasulullah Shallallahu Alaihi Wassallam melalui pesan-pesan da'wah yang disampaikan para anggota tim relawan da'wah muslimat Dewa Da'wah.

Realitas jumlah warga binaan wanita lebih banyak, dibandingkan jumlah tenaga dan fasilitas pembina napi wanita di lapas terbatas membuat Lapas membutuhkan bantuan pihak lain untuk membina para warga binaan. Lapas memerlukan bantuan pihak lain yang peduli akan masalah pembinaan sosial. Salah satu pihak yang peduli akan pembinaan ahlak warga binaan yaitu Dewan Da'wah Islamiyah Indonesia. Dengan pendekatan agama Islam dan komunikasi persuasif Dewan Da'wah Islamiyah Indonesia memberikan pencerahan rohani secara rutin tiga kali sepekan di Lapas Wanita Kelas IIA Tangerang. Dewan Da'wah mengirim para anggota relawan untuk membantu Lapas membimbing warga binaan untuk memahami ajaran Agama Islam sehingga warga binaan diharapkan dapat memiliki penerimaan diri atas situasi dan kondisi yang dihadapi sebagai ujian hidup dan kelak berubah ketika kembali kepada kehidupan masyarakat.

Berdasarkan uraian di atas, penulis merumuskan permasalahan dalam kalimatkalimat pertanyaan berikut:

1. Bagaimana penerimaan diri warga binaan wanita Lembaga Pemasyarakatan Wanita Kelas IIA Tangerang dalam menjalani masa tahanan?

2. Bagaimana penerimaan diri warga binaan wanita Lembaga Pemasyarakatan Wanita Kelas IIA Tangerang dalam menjalani masa tahanan pasca memperoleh pencerahan rohani agama Islam secara rutin oleh Tim Relawan Da'wah Muslimat Dewan Da'wah Islamiyah Indonesia sebagai salah satu bagian dari program membentuk mental positif warga binaan melalui program asimilasi?

\section{Landasan Teori dan Konsep}

\section{Penerimaan Diri.}

Penerimaan diri (self acceptance) ialah suatu kemampuan individu untuk dapat melakukakan penerimaan diri terhadap keberadaan diri. Hasil analisa atau penilaian terhadap diri sendiri akan dijadikan dasar bagi seorang individu untuk dapat mengambil suatu keputusan dalam rangka penerimaan terhadap keberadaan diri sendiri. Sikap 
penerimaan diri dapat dilakukan secara realistis, tetapi juga dapat dilakukan secara tidak realistis.Sikap penerimaan diri realiatis dapat ditandai dengan memandang segi kelemahan-kelemahan dan kelebihan-kelebihan diri secara objektif.Sebaliknya penerimaan diri tidak realistis ditandai dengan upaya menilai secara berlebihan diri sendiri, mencoba menolak kelemahan diri, mengingkari atau menghindari hal-hal buruk dalam dirinya, misalnya pengalaman traumatis masa lalu. ${ }^{1}$

Chaplin menambahkan, bahwa penerimaan diri adalah sikap yang pada dasarnya merasa puas pada diri sendiri, kualitas dan bakat diri serta mengakui keterbatasan diri sendiri. Penerimaan diri mengandaikan adanya kemampuan diri dalam psikologis seseorang yang menunjukkan kualitas diri. Hal ini berarti bahwa tinjauan tersebut akan diarahkan pada seluruh kemampuan diri yang mendukung. Kesadaran diri akan segala kelebihan dan kekurangan diri haruslah seimbang dan diusahakan untuk saling melengkapi satu sama lain, sehingga dapat menunmbuhkan kepribadian yang sehat. ${ }^{2}$

Hurlock (2004) mengemukakan tentang faktor-faktor yang mempengaruhi penerimaan diri adalah adanya pemahaman tentang diri sendiri, tidak adanya hambatan di dalam lingkungan, pengaruh keberhasilan yang dialami, baik secara kualitatif maupun kuantitatif, adanya hal yang realistik, sikap-sikap anggota masyarakat yang menyenangkan, tidak adanya gangguan emosional yang berat, dentifikasi dengan orangyang memiliki penyesuaian diri yang baik, adanya perspektif diri, pola asuh di masa kecil yang baik, dan konsep diri yang stabil ${ }^{3}$.

Selanjutnya Hurlock menambahkan bahwa bila individu hanya melihat dari satu sisi saja maka tidak mustahil timbul kepribadian yang timpang, semakin individu menyukai di sendiri, ia akan mampu menerima dirinya dan individu tersebut akan semakin diterima oleh orang lain yang mengatakan bahwa individu dengan penerimaan diri yang baik akan mampu menerima karakter-karakter alamiah dan tidak mengkritik sesuatu yang tidak bisa diubah lagi. ${ }^{4}$

\footnotetext{
${ }^{1}$ Dariyo Agoes. 2007. Psikologi Perkembangan anak usia tiga tahun pertama,Jakarta; PT Refika Aditama. Hal. 205

${ }^{2}$ Chaplin. J.P. 2005, Kamus Lengkap Psikologi, Jakarta, Raja Grafindo Persada. Hal.250

${ }^{3}$ Hurlock, E. B. 2004. Perkembangan anak. Jilid 2 (Edisi keenam). Jakarta : Erlangga.

${ }^{4}$ Hurlock. E.Adolescent Development , (4 ${ }^{\text {th }}$ ed.) (Internal Student Edition). 1979.Hal.434
} 
Sheerer (dalam Lestariningsih, 2008) mengungkapkan aspek penerimaan diri yaitu percaya kemampuan diri, perasaan sederajat, orientasi keluar, bertanggung jawab, berpendirian, menerima kelebihan dan kekurangan diri, menerima sifat kemanusiaan. ${ }^{5}$

Karakteristik utama dari penerimaan diri adalah spontanitas dan tanggung jawab pada diri, menerima kualitas kemanusiaannya tanpa menyalahkan diri sendiri untuk kondisi yang berada di luar kontrolnya. Individu dengan penerimaan diri yang tinggi tidak peduli akan berapa banyak kelemahan yang dimilikinya dan justru menjadikan kelemahan tersebut sebagai sumber kekuatan untuk kelebihannya. ${ }^{6}$

Hurlock berpendapat bahwa ada beberapa kondisi yang mendukung penerimaan diri individu, antara lain:

1. Pemahaman tentang diri sendiri (self understanding): adanya pemahaman tentang diri sendiri merupakan kesempatan seseorang untuk mengenali kemampuannya atau ketidakmampuannya. Semakin orang dapat memahami dirinya, semakin ia dapat menerima dirinya.

2. Pengharapan yang realistik (realistic expectation): Individu dapat menentukan sendiriharapannyayang disesuaikandenganpemahamandan kemampuannya, bukan diarahkan oleh orang lain sehinggadalam mencapai tujuannya memiliki harapan yang realistic.

3. Tidak adanya hambatan di dalam lingkungan(absence of environmental obstacles); Seseorang yang sudah memiliki harapan yang realistik tetapi lingkungan disekitarnya tidak memberikan kesempatan atau menghalanginya, harapan individu tersebut akan sulit tercapai.

4. Sikap anggota masyarakat yang menyenangkan (favourable social attitudes): Masyarakat memiliki prasangka yang baik karena adanya penghargaan terhadap kemampuan sosial dan kesediaan individumengikuti kebiasaanlingkungan.

5. Tidak adanya gangguan emosional yang berat (absence of emotional stress): Terciptanya individu yang dapat bekerja sebaik mungkin dan merasa bahagia karena tekanan emosi sekecil apapun dapat mengganggu keseimbanganindividu.

6. Pengaruh keberhasilan yang dialami, baiksecara kualitatif maupun kuantitatif (preponderance of success): Keberhasilan yang dialami individu akan dapat menimbulkan penerimaan diri dan sebaliknya jika kegagalan yang dialami individuakandapatmengakibatkanadanyapenolakandiri.

7. Identifikasi terhadap orang yang mampu menyesuaikan diri ((identification with well adjusted people): Individu yang mengidentifikasikanseseorang yang memiliki penyesuaian diri yangbaik akan dapat membangun sikap-sikap positifterhadap diri sendiri, dan bertingkah laku denganbaik menimbulkan penilaian dan penerimaan diri yang baik.

\footnotetext{
${ }^{5}$ Lestariningsih, T. 2008. Hubungan antara kestabilan emosi dengan penerimaan diri pada narapidana wanita. Skripsi: Fakultas Psikologi Universitas Muhammadiyah Surakarta.

${ }^{6}$ Hurlock, E. (1978). Personalitydevelopment. Tokyo: McGraw-Hill Publishing Company, Ltd.
} 
8. Adanya perspektif diri yang luas (self perspective): Memperhatikan pandangan orang lain tentang perspektif diri yang luas, diperoleh melalui pengalamandanbelajar.

9. Pola asuh dimasa kecil yang baik (good childhood training): Seorang anak yang diasuh secara demokratisakan cenderung berkembang sebagai individu yang dapat menghadapi dirinya sendiri.

10. Konsep diri yang stabil (stable self concept): Individu yang tidak memiliki konsep diriyang stabil, akan sulit menunjukkan pada oranglainsiapa iasebenarnya, sebabiasendiri ambivalen terhadap dirinya.

Sheerer (dalam Badaria dan Astuti, 2004, hal. 21-22) menyatakan beberapa ciri seseorang yang dapat menerima diri dengan baik yaitu :

a. Memiliki keyakinan akan kemampuan menghadapi hidup.

b. Menganggap dirinya berharga sebagai seorang manusia, sederajat dengan orang lain.

c. Tidak menganggap diri aneh dan tidak beranggapan orang lain menolaknya.

d. Tidak malu dan tidak memperhatikan dirinya.

e. Berani memikul tanggungjawab atas perilakunya.

f. Dalam berperilaku menggunakan norma dirinya.

g. Mampu menerima pujian serta celaan secara objektif.

h. Mampu menerima keterbatasan dalam dirinya. ${ }^{8}$

\section{Komunikasi Da'wah}

Definisi komunikasi menurut Harold Laswell dalam karyanya, The Structure and function of Communicationin Society, bahwa cara yang baik dalam merumuskan komunikasi adalah dengan menjawab sebuah pertanyaan Who Says What In Which Channel To Whom With What Effect atau Siapa Mengatakan Apa Dengan Saluran Apa Kepada Siapa Dengan Pengaruh Bagaimana?.?

Dari definisi Laswell tersebut komunikasi dapat diambil lima komponen dalam komunikasi yaitu komunikator, pesan, media, komunikan dan efek. Komunikator merupakan sumber informasi yang mempunyai tujuan dalam komunikasi. Tujuan-tujuan yang dilakukan komunikator sesuai apa yang diperlukan oleh komunikator, seperti dapat mengubah karakter orang lain atau pendapat orang lain. Pesan yaitu segala sesuatu yang dikomunikasikan oleh komunikator berupa simbol verbal maupun non verbal untuk

\footnotetext{
${ }^{7}$ Hurlock, E. (1978). Personalitydevelopment. Tokyo: McGraw-Hill Publishing Company, Ltd.Hal. 434-436.

${ }^{8}$ Badaria, H; Astuti, YD. 2004.Religiusitas dan Penerimaan Diri pada Penderita Diabetes Mellitus. Psikologika Nomor 17 Tahun IX

${ }^{9}$ Effendy, Onong Uchjana. 2008. Ilmu Komunikasi, Teori \& Praktik. Bandung : PT. Remaja Rosdakarya
} 
mewakili gagasan atau pemikiran dari komunikator tersebut.Pesan itu sendiri mempunyai tiga unsur yakni makna, simbol yang digunakan untuk menyampaikan makna dan bentuk pesan itu sendiri.Media adalah alat yang dipakai oleh komunikator untuk menyampaikan pesan dan diterima oleh komunikan. Media ini tergantung pesan yang akan disampaikan oleh komunikator, bisa berupa media verbal ataupun nonverbal.Komunikan merupakan unsur dari komunikasi dalam menerima pesan dari komunikator.Komunikan memahami pesan berdasarkan pemahaman masa lalu dalam menafsirkan pesan yang disampaikan oleh komunikator. Efek merupakan apa yang terjadi dalam pikiran komunikan setelah ia menerima pesan yang dijelaskan oleh komunikator. Efek dapat mendapatkan persetujuan, ketidak setujuan, perubahan keyakinan, dan perubahan sikap dari komunikan.

Dalam penelitian ini, teknik komunikasi yang digunakan adalah teknik komunikasi persuasi. Menurut Carl I Hovland (dalam Sunarjo dan Djoenaesih, 1983) persuasi adalah efek umum dari komunikasi persuasi terletak pada dorongan supaya setiap personal berpikir dalam dua segi yaitu pendapatnya sendiri dan pendapat baru yang diajukan oleh orang lain. ${ }^{10}$

Pada umumnya, komunikasi sudah memenuhi dari kegiatan persuasi, seperti yang dijelaskan oleh Erwin P. Betting House (dalam Widjaja, 1993) keadaan komunikasi harus mencakup upaya seseorang yang dengan sadar mengubah tingkah laku orang lain atau sekelompok orang lain melalui penyampaian beberapa pesan. ${ }^{11}$ Tujuanpokok dari persuasi merupakan mempengaruhi pikiran, perasaan dan tingkah laku seseorang, kelompok untuk kemudian melakukan tindakan/ perbuatan sebagaimana yang dikehendaki.

Kemudian, da'wah secara arti bahasa yaitu panggilan,seruan ataupun ajakan, bentuk pengucapan tersebut dalam bahasa Arab disebut mashdar, sedangkan bentuk kata kerja (fi'il) nya berarti memanggil, menyeru atau mengajak (Da'a, Yad'u, Da'watan). ${ }^{12}$

Dakwah menurut Hamka yaitu ajakan panggilan untuk menganut suatu pendirian yang ada dasarnya berkonotasi positif dengan substansi terletak pada aktivitas yang memerintahkan amar ma'ruf dan nahi mungkar. ${ }^{13}$ Dari definisi yang dijelaskan oleh Hamka tersebut, dapatlah di tarik kesimpulan, mengajak umat dalam berbuat kebaikan, mengenalkan Ketuhanan, membimbing kepada jalan yang lurus, mengajarkan untuk amar

\footnotetext{
${ }^{10}$ Sunarjo dan Djonaesih S. Sunarjo.1983.Komunikasi Persuasif dan Retorika. Yogyakarta : Liberty

${ }^{11}$ Widjaja, A.W.1986. Komunikasi Komunikasi dan Hubungan Masyarakat. Jakarta : Bumi Aksara

${ }^{12}$ Saputra, Wahidin. 2011. Pengantar Ilmu Dakwah. Jakarta: PT. RajaGrafindo Persada

${ }^{13}$ Ibid.h. 1
} 
makruf dan nahi munkar, demi kemaslahatan dunia dan akhirat. Dari definisi komunikasi dan dakwah tersebut maka istilah komunikasi dakwah merupakan ajakan yang dilakukan oleh komunikator dakwah dalam hal ini da'i, untuk mengajak komunikan dakwah dalam hal ini jamaahnya, dengan cara komunikasi verbal maupun non verbal, bertujuan kebaikan dunia dan akhirat.

Penelitian dengan pendekatan kualitatif ini menggunakan paradigma konstruktivis. Paradigma konstruktivis, yaitu paradigma yang hampir merupakan antitesis dari paham yang meletakkan pengamatan dan objektivitas dalam menemukan suatu realitas atau ilmu pengetahuan.Paradigma ini memandang ilmu sosial sebagai analisis sistematis terhadap socially meaningful action melalui pengamatan langsung dan terperinci terhadap perilaku sosial yang bersangkutan menciptakan dan memelihara atau mengelola dunia sosial mereka. ${ }^{14}$

Menurut Patton (1978), para peneliti konstruktivis mempelajari beragam realita yang terkonstruksi oleh individu dan implikasi dari konstruksi tersebut bagi kehidupan mereka dengan yang lain. Dalam konstruktivis, setiap individu memiliki pengalaman yang unik. Dengan demikian, penelitian dengan strategi seperti ini menyarankan bahwa setiap cara yang diambil individu dalam memandang dunia adalah valid, dan perlu adanya rasa menghargai atas pandangan tersebut. Paradigma konstruktivis memiliki beberapa kriteria yang membedakannya dengan paradigma lainnya, yaitu ontologi, epistemologi, dan metodologi.Level ontologi, paradigma konstruktivis melihat kenyataan sebagai hal yang ada tetapi realitas bersifat majemuk, dan maknanya berbeda bagi tiap orang.

Dalam epistemologi, peneliti menggunakan pendekatan subjektif karena dengan cara itu bisa menjabarkan pengkonstruksian makna oleh individu. Dalam metodologi, paradigma ini menggunakan berbagai macam jenis pengkonstruksian dan menggabungkannya dalam sebuah konsensus. Proses ini melibatkan dua aspek: hermeunetik dan dialetik. Hermeunetik merupakan aktivitas dalam merangkai teks percakapan, tulisan atau gambar. Sedangkan dialetik adalah penggunaan dialog sebagai pendekatan agar subyek yang diteliti dapat ditelaah pemikirannya dan membandingkannya dengan cara berpikiri peneliti. Dengan begitu, harmonitas komunikasi dan interaksi dapat dicapai dengan maksimal. ${ }^{15}$

\footnotetext{
${ }^{14}$ Dedy N. Hidayat. 2003. Paradigma dan Metodologi Penelitian Sosial Empirik Klasik, Jakarta : Departemen Ilmu Komunikasi FISIP Universitas Indon

${ }^{15}$ Ibid.
} 
Dalam rangka mencapai tujuan penelitian sekaligus menjawab pertanyaan dalam rumusan masalah, peneliti menggunakan metode penelitian yang relevan dengan permasalahan penelitian. Menurut Darmadi (2013:153), Metode penelitian adalah suatu cara ilmiah untuk mendapatkan data dengan tujuan kegunaan tertentu. Cara ilmiah berarti kegiatan penelitian itu didasarkan pada ciri-ciri keilmuan yaitu rasional, empiris, dan sistematis. Kaidah-kaidah penelitian dalam pendekatan penelitian kualitatif dengan metode studi kasus menjadi pedoman peneliti mengkaji tema penerimaan diri warga binaan di lapas Tangerang setelah rutin mendapat pencerahan rohani dari tim relawan da'wah Muslimat Center Dewan Da'wah Islamiyah Indonesia.

Penelitian ini memusatkan diri secara intensif pada satu obyek tertentu yang mempelajarinya sebagai suatu kasus. Data studi kasus dapat diperoleh dari semua pihak yang bersangkutan, dengan kata lain dalam studi ini dikumpulkan dari berbagai sumber (Nawawi, 2003: 1).

Penelitian studi kasus akan kurang kedalamannya bilamana hanya dipusatkan pada fase tertentu saja atau salah satu aspek tertentu sebelum memperoleh gambaran umum tentang kasus tersebut. Sebaliknya studi kasus akan kehilangan artinya kalau hanya ditujukan sekedar untuk memperoleh gambaran umum namun tanpa menemukan sesuatu atau beberapa aspek khusus yang perlu dipelajari secara intensif dan mendalam. Studi kasus yang baik harus dilakukan secara langsung dalam kehidupan sebenarnya dari kasus yang diselidiki. Walaupun demikian, data studi kasus dapat diperoleh tidak saja dari kasus yang diteliti, tetapi, juga dapat diperoleh dari semua pihak yang mengetahui dan mengenal kasus tersebut dengan baik. Dengan kata lain, data dalam studi kasus dapat diperoleh dari berbagai sumber namun terbatas dalam kasus yang akan diteliti (Nawawi, 2003: 2).

Yin (1994: 21) menyatakan bahwa tidak cukup jika pertanyaan Studi Kasus hanya menanyakan "apa", (what), tetapi juga "bagaimana" (bow) dan "mengapa" (why). Pertanyaan "apa" dimaksudkan untuk memperoleh pengetahuan deskriptif (descriptive knowledge), "bagaimana" (how) untuk memperoleh pengetahuan eksplanatif (explanative knowledge), dan "mengapa" (why) untuk memperoleh pengetahuan eksploratif (explorative knowledge). Yin menekankan penggunaan pertanyaan "bagaimana" dan "mengapa", karena kedua pertanyaan tersebut dipandang sangat tepat untuk memperoleh pengetahuan yang mendalam tentang gejala yang dikaji. 
Teknik pemilihan sumber data/informan penelitian yang digunakan pada penelitian ini adalah purposive sampling. Herdiansyah menjelaskan bahwa purposive sampling adalah teknik dalam nonprobability sampling yang berdasarkan kepada ciri-ciri yang dimiliki oleh subyek yang dipilih karena ciri-ciri tersebut sesuai dengan tujuan penelitian yang akan dilakukan ${ }^{16}$.

Data-data yang menggambarkan penerimaan diri para warga binaan wanita di Lapas diperoleh melalui pengumpulan data ke lapangan penelitian. Tehnik pengumpulan data yang digunakan adalah triangulasi yaitu menggabungkan beberapa tehnik untuk memperoleh data primer dan data sekunder. Data primer diperoleh melalui wawancara mendalam dan pengamatan kepada informan penelitian yang sudah ditentukan secara purposive. Sedangkan data sekunder diperoleh melalui studi dokumentasi, yaitu melakukan elaborasi lewat berbagai literatur terkait tema penelitian.

Wawancara-Mendalam (In-depth Interview) adalah proses memperoleh keterangan untuk tujuan penelitian dengan cara tanya jawab sambil bertatap muka antara pewawancara dengan responden atau orang yang diwawancarai, dengan atau tanpa menggunakan pedoman (guide) wawancara dimana pewawancara dan informan terlibat dalam kehidupan sosial yang relatif lama (Sutopo 2006: 72). Maka peneliti melakukan wawancara mendalam kepada informan penelitian yaitu warga binaan di Lapas Wanita Kelas IIA Tangerang yang rutin mengikuti kegiatan rutin pencerahan rohani dari anggota tim relawan da'wah muslimat Dewan Da'wah dalam program asimilasi. Selain mengumpulkan data melalui wawancara mendalam kepada subyek penelitian, peneliti juga melakukan pengamatan langsung yaitu mengamati perilaku para warga binaan ketika mengikuti kegiatan pencerahan ronahi.Observasi merupakan kegiatan pengamatan secara inderawi peneliti yang direncanakan, sistematis dan hasilnya dicatat serta diinterpretasikan dalam rangka memperoleh pemahaman tentang objek yang diamati. Observasi juga dilakukan ketika peneliti mengadakan percakapan dengan informan penelitian.

Setelah data terkumpul dan berada pada kondisi data jenuh, peneliti masuk pada tahap analisa data dengan tehnik analisa data model Milles dan Haberman. Analisis data kualitatif model Milles dan Hubermen terdapat 3 (tiga) tahap:

1. Tahap Reduksi Data

${ }^{16}$ Herdiansyah, H. (2012). Metodologi Penelitian Kualitatif untuk IlmuIlmu Sosial. Jakarta: Salemba Humanika. 
Sejumlah langkah analisis selama pengumpulan data menurut Milles dan Huberman adalah : meringkaskan data, melakukan pengkodean terhadap data dilanjutkan dengan mengklasifikasikan data hingga akhirnya data diberi label. Peneliti dituntut dapat melakukan aktivitas reduksi data secara mandiri untuk mendapatkan data yang mampu menjawab pertanyaan penelitian.

\section{Tahap Penyajian Data/ Analisis Data Setelah Pengumpulan Data}

Pada tahap ini peneliti banyak terlibat dalam kegiatan penyajian atau penampilan (display) dari data yang dikumpulkan dan dianalisis sebelumnya, mengingat bahwa peneliti kualitatif banyak menyusun teks naratif. Display adalah format yang menyajikan informasi secara tematik kepada pembaca. Milles dan Huberman (1984) memperkenalkan dua macam format, yaitu : diagram konteks (context chart) dan matriks.

\section{Tahap Penarikan Kesimpulan dan Verifikasi}

Langkah selanjutnya adalah tahap penarikan kesimpulan berdasarkan temuan dan melakukan verifikasi data. Seperti yang dijelaskan di atas bahwa kesimpulan awal yang dikemukakan masih bersifat sementara dan akan berubah bila ditemukan bukti-bukti buat yang mendukung tahap pengumpulan data berikutnya. Proses untuk mendapatkan buktibukti inilah yang disebut sebagai verifikasi data. Apabila kesimpulan yang dikemukakan pada tahap awal didukung oleh bukti-bukti yang kuat dalam arti konsisten dengan kondisi yang ditemukan saat peneliti kembali ke lapangan maka kesimpulan yang diperoleh merupakan kesimpulan yang kredibel.

Agar hasil penelitian kualitatif ini dinilai baik, Poerwandari (2001:102-106) mengatakan bahwa ada lima kriteria yang harus dipenuhi peneliti antara lain: Pertama keterbukaan yaitu intensitas peneliti mendiskusikan hasil temuannya dengan orang lain yang dianggap menguasai bidang tema penelitian. Kriteria kedua konformabilitas yaitu kesediaan peneliti mengungkapkan secara terbuka proses dan elemen-elemen penelitiannya sehingga memungkinkan orang lain melakukan penelitian. Ketiga kebenaran, kebenaran yang dimaksud di sini adalah kebenaran yang sebagian besar tergantung pada perspektif orang yang terlibat di dalamnya dan oleh karenanya tergantung pada konteks situasi sekaligus internal pemberi defenisi. Selanjutnya kriteria keempat kredibilitas ialah terletak pada keberhasilan mencapai maksud, kemampuan mengeksplorasi masalah, mendeskripsikan seting, proses, kelompok sosial atau pola interaksi yang kompleks. Peneliti berhasil menggali semua informasi yang dibutuhkan dalam satu kali wawancara mendalam. Kriteria terakhir adalah transfebilitas yakni 
sejauh mana penelitian yang dilakukan pada suatu kelompok dapat diaplikasikan pada kelompok lain dengan memperhatikan seting dan konteks dalam mana studi akan dipindahkan haruslah relevan atau memiliki kesamaan.

\section{HASIL DAN DISKUSI}

Lapas Wanita Kelas II A Tangerang beralamat di Jl. Mochammad Yamin No.1, RT.001/RW.004, Babakan, Kecamatan Tangerang, Kota Tangerang, Banten 15118. Diresmikan penggunaannya 5 Februari 1981 dan merupakan pindahan dari Bukit Duri, Jakarta. Pemerintah memindahkan Lapas Wanita ke Tangerang tersebut karena dianggap sudah tidak sesuai dengan tata letak Jakarta.

Lembaga Pemasyarakatan Perempuan Kelas II A Tangerang dibangun di atas lahan sekitar 7,28 hektar dengan luas bangunan 1,69 hektar dan kapasitas huni sebanyak 250 orang, mayoritas penghuni berada di Lapas dengan latarbelakang kasus narkoba. Memiliki 23 unit bangunan yaitu 5 unit perkantoran, 6 unit bangunan hunian warga binaan, ruang admisi orientasi, ruang pelatihan bunga kering dan ruang isolasi, ruang dapur, ruang serba guna, aula, ruang isolasi perawatan, ruang poliklinik, bangunan mushola, bangunan gereja, lapangan olah raga, ruang koperasi dan ruang kunjungan.

Ruang Mushola An-Nisa diperuntukkan untuk kegiatan melaksanakan ibadah wajib lima waktu para warga binaan, pembinaan rohani seperti kajian Agama Islam oleh para relawan dari berbagai pihak Dewan Da'wah Islamiyah Indonesia; Tajwid dan Tahsin serta kajian intensif program asimilisasi (pencerahan Agama Islam bagi para warga binaan yang masa hukumannya mendekati akhir).

Visi Lembaga Pemasyarakatan Perempuan Kelas IIA Tangerang adalah "Mewujudkan manusia yang beriman, bertakwa, aktif dan produktif serta bertanggung jawab dalam kehidupan bermasyarakat" Selanjutnya Misi Lembaga Pemasyarakatan Perempuan Kelas IIA Tangerang yaitu "Melaksanakan pembinaan mental spiritual baik rohani dan jasmani yang bertujuan untuk meningkatkan kesadaran sebagai mahluk mandiri, anggota masyarakat dan mahluk Tuhan Yang Maha Esa."

Berdasarkan Visi dan Misi Lembaga Pemasyarakatan Perempuan Kelas IIA Tangerang tersebut terlihat bahwa Lapas terus berupaya melaksanakan rangkaian kegiatan membina perempuan narapidana di sana sesuai Visi dan Misi yang ingin diwujudkan. 
Bentuk dari rangkaian usaha mewujudkan Visi dan Misi Lembaga Pemasyarakatan Perempuan Kelas II A Tangerang yakni melakukan pembinaan rohani kepada para warga binaan. Dalam melaksanakan pembinaan rohani pihak Lapas dibantu beberapa pihak relawan. Salah satunya yaitu Dewan Da'wah Islamiyah Indonesia yang diwakili tim relawan Muslimat Center Dewan Da'wah. Pembinaan rohani dilakukan melalui kegiatan kajian rutin Agama Islam tiap Rabu dan program asimilasi 2 kali sepekan Rabu dan Jumat. Umumnya peserta rutin kajian Agama Islam di mushola An-Nisa diikuti sekitar 50 orang dari sekitar 200 warga binaan yang beragama Islam. Bidang Pembinaan Rohani yang dipimpin Ibu Nur sebelum waktu kajian selalu mengumumkan melalui pengeras suara kepada wargaa binaan terkait kegiatan pencerahan agama. Kegiatan pencerahan Agama Islam melalui kajian rutin Rabu wajib diikuti oleh warga binaan, namun belum semua warga binaan memiliki kesadaran akan pentingnya mengikutinya.

Selain kajian rutin Rabu ada kegiatan asimilasi, dalam kegiatan ini pembimbing Agama Islam yaitu anggota tim relawan da'wah Muslimat Ceter Dewan Da'wah Islamiyah Indonesia secara intensif membantu para warga binaan yang masa tahanannya mendekati akhir memperoleh pengetahuan agama Islam lebih dalam sebagai bekal warga binaan lebih siap lahir dan batin kembali bermasyarakat ketika datang masa bebas. Dalam program ini diajarkan terutama tentang ketauhidan (mengenal Allah sebagai pencipta langit-bumi dan isinya), fikih shalat wajib dan sunnah, amalan ibadah harian seperti zikir pagi dan petang, fikih wanita hingga ahlakul kharimah.

Peserta kajian rutin Rabu dan program asimilasi umumnya menunjukkan sikap belum maksimal termotivasi dan terwarnai pencerahan agama Islam, oleh karena itu menjadi tantangan bagi para pembimbing untuk lebih sabar dalam mencari strategi metode terbaik untuk membimbing para warga binaan agar memiliki dan memahami ilmu Agama Islam dan lebih baik di masa depan setelah bebas dari penjara.

Kerja sama pembinaan rohani melalui kegiatan rutin pencerahan Agama Islam antara pihak Lapas dan Dewan Da'wah dilakukan sejak awal 2015 hingga sekarang. Anggota Tim Relawan Da'wah Muslimat Center sebagai bagian dari Bidang Sosial Dewan Da'wah Islamiyah Indonesia secara bergantian sesuai jadual yang telah diatur datang ke Lapas memberikan pembinaan rohani.

Hasil wawancara menunjukkan bahwa para peserta kajian rutin Rabu yang diwakili tiga warga binaan sebagai informan menyatakan bahwa sebelum mereka mengikuti kegiatan kajian rutin Rabu merasakan beban cukup berat dalam hati dan pikiran. Takut menghadapi stigma narapidana yang ada di masyarakat, takut tidak memiliki masa depan yang baik lagi, takut kelak bebas tidak diterima oleh lingkungan dan sulit dapat pekerjaan karena predikat mantan 
narapidana, takut bertemu keluarga atau bahkan tidak diterima oleh keluarga, serta berbagai rasa takut lainnya.

Gambaran berbagai rasa takut warga binaan peserta program asimilasi dapat diambil kesimpulan bahwa warga binaan membutuhkan waktu lama untuk menerima dirinya dengan status saat menjalani hukuman maupun yang akan datang. Kecemasan dan penerimaan diri warga binaan dalam kondisi labil. Idealnya penerimaan diri penting dimiliki warga binaan selama menjalani masa hukuman, karena penerimaan diri merupakan salah satu ciri terpenting dalam penyesuaian diri warga binaan terhadap kondisi proses hukuman yang akan dijalani.

Sebagian warga binaan memiliki perasaan ragu dan terbebani mengenai kemampuan diri untuk beradaptasi di lingkungan Lapas. Meskipun demikian ada harapan yang muncul dalam hati bahwa yakin kelak dapat keluar dari penjara apabila tidak melanggar dan mematuhi peraturan di Lapas sehingga hukumannya akan berkurang. Hukuman seumur hidup akan menjadi hukuman angka melalui grasi yang hanya bisa diberikan oleh presiden. Oleh karena itu ketiga warga binaan tersebut memotivasi diri dengan rajin mengikuti kajian rutin Rabu dan program asimilasi.

Pengajaran agama Islam dipandang sebagai suatu usaha mengubah tingkah laku, yang diharapkan setelah mempelajari pelajaran Agama Islam adanya perubahan tingkah laku yang diharapkan meliputi tiga aspek, yaitu aspek kognitif, afektif, dan perilaku. Pengajaran agama Islam oleh anggota tim relawan da'wah Muslimat Center berharap memberikan perubahan yang lebih baik kepada narapidana.

Awal pembinaan melalui program asimilasi terlihat sikap warga binaan mempunyai masalah jauh dari pengetahuan agama, seperti adab bermajelis tampak pada gesture dan grooming (penampilan dari ujung kepala hingga kaki) mereka. Warga binaan tampil dengan celana sedengkul, kerudung terkesan hanya menempel menutupi rambut yang masih terlihat bebas, sikap duduk selonjor kaki. Hingga akhirnya proses pembinaan berhasil mengubah sedikit demi sedikit gesture dan grooming warga binaan tersebut. Mengikuti pengajaran Agama Islam di secara rutin di mushola An-Nisa secara perlahan menumbuhkan kembali nilai-nilai Islam didalam dirinya dan terus mengikuti pengajaran agama Islam untuk memotivasi diri agar selalu lebih baik dan bermanfaat, sehingga saat bebas nanti dapat diterima masyarakat bahkan warga binaan bisa mengamalkan apa yang sudah diajarkan.

Data untuk mengetahui bahwa ada perubahan dari warga binaan dapat peneliti amati ketika berinteraksi dalam pkegiatan program asimilasi, antara lain warga binaan ada yang sudah bisa membaca Al-Qur`an di mana menurut warga binaan tersebut awalnya tidak bisa mengaji. Kemudian terkait penerimaan diri seorang informan mengatakan bahwa saat pertama kali masuk 
Lapas ia selalu menangis dan tidak bisa menerima keputusan mendapatkan hukuman di dalam Lapas selama dua belas tahun sampai akhirnya setelah rutin mengikuti kajian rutin Agama Islam di mushola dan bisa mengikuti program asimilasi, warga binaan menerima keadaannya dan berserah diri pada Allah Subhaana Wa Ta'aala. Mengenal keagungan Allah Ta'aala membuat warga binaan tersebut berupaya menumbuhkan motivasi dalam diri untuk memperbaiki diri dan tidak mudah patah semangat. Meskipun dirinya menyadari ada masa di mana dirinya pernah labil dan nyaris patah semangat.

Peneliti melakukan wawancara kepada tiga warga binaan mengenai perubahan sebelum dan sesudah mendapatkan pengajaran agama Islam seperti diuraikan dalam kutipan berikut:

Tati (41 Tahun) “Dahulu saya adalah ibu rumah tangga biasa, suatu masa menghianati suami yaitu akrab dengan lelaki lain. Saya tidak tahu kalo teman lelaki saya seorang pengedar narkoba. Emang sih awalnya saya ga ngeladenin dia waktu ngajak kenalan, tapi lama kelamaan terayu juga. Sampe suatu saat dia minta alamat rumah saya, katanya ada barang dagangan yang mau datang dari India, karena ga punya alamat tetap di Jakarta, dia minta tolong pake alamat rumah saya. Mungkin ini karma buat saya karena hianat ama suami, ternyata itu barang dagangan yang datang dari India isinya heroin $12 \mathrm{~kg}$. Akhirnya saya dibui 12 tahun gara-gara nerima itu barang, Saya ngerasa dosa ama suami dan ibu saya yang udah sakit-sakitan. Saya terus berdoa semoga ibu saya masih hidup waktu saya udah bebas nanti. Karena kalo sampe ibu saya meninggal tapi saya masih di penjara, saya ngerasa jadi anak durhaka. Masa tahanan saya tinggal 3 bulan lagi, mudah-mudahan waktu saya keluar nanti ibu saya masih hidup dan saya mau tobat." 17

Selanjutnya informan kedua adalah Tya (21 th): "Alhamdulillah ini hukuman 10 tahun di dunia membuat saya tobat, banyak yang saya dapatkan di mushola ini sehingga banyak perubahan yang saya rasakan seperti saya sudah termotivasi untuk puasa sunnah, selalu shalat lima waktu, mengaji huruf hijaiyah dan Alhamdulillah saya sudah mengaji Al-Qur'an pada awalnya saya tidak bisa dan belajar Iqra dan saya sangat bersyukur sekarang masa hukuman saya sudah berjalan separuhnya dan lagi nunggu proses bebas bersyarat. Sambil nunggu proses bebas bersyarat saya banyak menghafal al-qur'an di sini. Saya merasa sekarang ini sudah lebih tenang karena sebelumnya saya tidak terima keadaan saya karena terjebak bisnis narkoba. Tapi mungkin ini adalah rencana Allah, saya mendapatkan motivasi untuk lebih sabar atas kasus saya, dan menganggap di sini jadi Pondok Pesantren sehingga lebih tenang keadaan saya dan menerima semuanya. Saya bersyukur sekarang bisa mengaji, nanti saat keluar bisa saya ajarkan ke adik-adik saya. ${ }^{18}$

Kemudian informan ketiga Biah (47 th): "Rencana Allah selalu lebih baik tapi kita yang tidak sadar hal itu. Awalnya saya bingung dan belum terbayangkan bagaimana akan mengisi harihari saya selama menjalani masa hukuman. Hingga akhirnya saya terpilih menjadi tamping di mushola An-Nisa. Sejak saat itu saya jadi tahu bahwa saya akan mengisi hari-hari saya di mushola An-Nisa. Saat saya perpilih menjadi tamping di mushola, saya pikir Allah telah memberika saya hidayah karena selama dua tahun jadi tamping saya rajin beribadah, menghadiri kegiatan tausiyah,

\footnotetext{
${ }^{17}$ Hasil wawancara dengan tati (September 2019 Jumat ke-3 saat mengikuti program asimilasi) di mushola AnNisa

${ }^{18}$ Hasil wawancara dengan Tya (September 2019 Jumat ke-3 saat mengikuti program asimilasi) di mushola AnNisa
} 
mencatat dan mempelajari ulang pelajaran yang diberikan di kegiatan pengajian. Tapi saya bingung kenapa hati saya masig ngerasa gersang. Hingga suatu saat di kegiatan tausiyah saya merasa tersentak mendengar satu ayat Al-Qur'an yang dibacakan seorang ustadzah. Ayat tersebut membuat saya sadar bahwa saya belum sepenuhnya bertobat dan harus lebih bertobat. Sejak itu saya bertekad harus berubah dan saya merasa lebih tenang, saya rutin selalu mengaji ibaratnya ajara-ajaran agama Islam seperti bengkel hati saya, saya lagi rusak dan harus dibetulkan di dalam diri, saya harus lebih sabar dan sadar ini adalah ketetapan Allah Subhaana Wa Ta'aala." ${ }^{19}$

Dalam mengatasi masalah tersebut seperti yang diuraikan ketiga informan, masingmasing berupaya mengubah diri dengan serius mengikuti kegiatan pembinaan agama yang diberikan anggota tim relawan da'wah sehingga Allah mengijinkan mereka mendapat hidayah dan termotivasi supaya memanfaatkan waktu luang mereka dengan belajar Agama Islam dan hal-hal yang akan membantu warga binaan memiliki kesiapan diri baik lahir maupun batin untuk kembali kepada masyarakat. Namun demikian menurut ketiga informan mereka masih butuh waktu untuk proses perubahan dalam diri tidak mudah untuk ketiganya dan terkadang godaan malas dan kurang yakin merasuki hati mereka.

Metode pembelajaran yang diberikan anggota tim relawan da'wah Muslimat Center kepada warga binaan yang mengikuti program asimilasi yaitu dengan metode interaktif. Materi disampaikan dengan menggunakan alat bantu proyektor. Buku saku tata cara shalat sesuai contoh shalat Rasulullah, foto copi materi yang dibahas. Sekitar 30 menit digunakan untuk menyampaikan materi dengan bahasa yang mudah dipahami warga binaan dan dalil-dalil bersumber dari Al-qur'an juga hadist shahih dan hasan Rasulullah Shallallahu alaihi wassallam. Selanjutnya peserta diberikan kesempatan menyampaikan hal-hal yang ingin ditanyakan dan di akhir pembelajaran pembimbing akan mengevaluasi materi yang telah disampaikan melalui soal jawab kepada peserta layaknya belajar mengajar di ruang kelas. Di akhir pembinaan pembimbing rohani Islam akan memberi penilaian atas perkembangan pemahaman peserta di buku monitor masing-masing peserta.

Kesulitan atau hambatan kecil muncul karena kadang-kadang beberapa peserta datang terlambat. Pembimbing telah datang di mushola jam 13.00 WIB tapi peserta datang tiga puluh menit kemudian, padahal pihak Lapas sudah secara berulang menginformasikan melalui pengeras suara bahwa kegiatan program asimilasi akan segera dilaksanakan dan pembimbing rohani sudah tiba di mushola An-nisa. Kesulitan lain yaitu pembimbing harus menyediakan buku-buku yang dibutuhkan untuk dibaca warga binaan karena Lapas tidak memfasilitasi hal tersebut. Oleh

\footnotetext{
${ }^{19}$ Hasil wawancara dengan Biah (September 2019 Jumat ke-3 saat mengikuti program asimilasi) di mushola AnNisa
} 
karena itu pembimbing rohani harus mencari dana dari para muhsinin atau mengeluarkan dana sendiri untuk memfasilitasi buku-buku Agama Islam yang dibutuhkan warga binaan.

Lillahi Ta`ala menjadi prinsip bagi anggota tim relawan da’wah dalam membimbing para warga binaan. Jarak tempuh yang cukup jauh dari wilayah Jakarta Timur menuju Tangerang menjadi tantangan tersendiri bagi para relawan da'wah. Bahan materi seperti foto copy dan buku dari uang sendiri atau muhsinin, karena ini bidang sosial pengajarnya pun yang datang tidak mengharapkan upah dari Lapas atau Dewan Da'wah. Oleh karena itu disebut prinsip hanya karena Allah Ta'aala.

Terkait pemberian materi pembimbing harus sering melakukan review materi yang minggu lalu agar warga binaan yang baru masuk mendapatkan ilmunya.

Selama berada di Lembaga Pemasyarakatan, warga binaan pemasyarakatan menyadari bahwa mereka jauh dari keluarga, dijauhi oleh lingkungan sosialnya, serta memiliki kebebasan yang terbatas. Keadaan serba terbatas ini menyebabkan warga binaan pemasyarakatan merasa tidak nyaaman, cemas, dan ingin segera bebas. Namun disisi lain warga binaan pemasyarakatan merasa takut untuk bebas karena membayangkan nantinya ada penolakan sosial, pengasingan, dan pengucilan dari masyarakat, serta sulitnya mendapatkan pekerjaan.

Mengikuti pembinaan kerohanian menjadi salah satu pilihan bagi warga binaan agar menerima kondisi dirinya dalam proses menjalani masa hukuman. Ketika warga binaan telah sampai pada perasaan dapat menghubungkan diri melalui ibadah wajib dan sunnah kepada Allah Ta'aala, warga binaan merasakan lebih dekat dengan Allah sehingga muncul keinginan dalam hati ingin makin mendekatkan diri pada Allah Ta'aala, maka biasanya warga binaan akan menseting diri lebih lama berada di mushola An-Nisa dengan aktivitas membaca Al-qur'an, namun sedikit yang memiliki minat membaca kitab-kitab yang telah disediakan di perpustakaan mini mushola. Selain itu melakukan shalat sunnah sebelum dan sesudah shalat fardhu dan membaca zikir pagi dan petang serta dzikir yang kapan saja bisa diucapkan sesuai tuntunan Rasulullah Shallallahu Alaihi Wassallam.

Ketiga informan menyatakan bahwa membangun hubungan dengan Allah membawa kelegaan tersendiri dalam hati mereka. Batinnya menjadi lebih tenang dan nyaman, seperti mendapatkan pencerahan baru. Hal ini serupa seperti yang diungkapkan oleh Seligman, (2005). Orang yang religius lebih bahagia dan lebih puas terhadap kehidupan daripada orang yang tidak religius. Hal ini dikarenakan agama memberikan harapan akan masa depan dan menciptakan makna dalam hidup bagi manusia tersebut (Seligman, 2005). 
Informan pertama merasa sudah berusaha untuk memaafkan dan melupakan kejadian di masa lalunya. Ia menganggap kejadian yang telah ia alami sebagai bahan pembelajaran untuk ke depannya dan tidak ingin mengulanginya kembali mengingat ia memiliki seorang putra yang sudah remaja. Informan pertama juga sudah meminta maaf kepada suami dan berharap kelak suaminya mau memaafkan dan menerima dirinya kembali menjadi isteri. Ia berjanji akan menjadi isteri yang baik. Informan pertama mempunyai keyakinan di masa depannya akan lebih baik karena ia berkelakuan baik di dalam penjara sehingga memdapat keringanan masa tahanan. Informan pertama juga merasa senang karena memiliki hubungan baik dengan warga binaan lainnya dan petugas lapas. Bahkan ia dipercaya mengelola wartel di dalam Lapas. Informan merasa ada hambatan mengikuti kegiatan keagamaan karena wartel tidak bisa ditinggalkan. Dengan adanya program asimilasi informan merasa terbantu mempelajari Agama Islam. Meskipun ia merasa belum secara maksimal bisa hijrah seperti menggunakan pakaian yang menutup auratnya. Menurutnya mendengarkan hal-hal baik setiap hari membuatnya sedikit demi sedikit mengalami perubahan, seperti menjadi penyabar. Mendengarkan hal-hal baik seperti memberikan motivasi untuknya bahwa ia masih berharga dimata Allah.

Secara umum warga binaan masih mampu mengenali diri sendiri serta dapat menjadi lebih sadar akan realitas yang sedang dijalaninya di penjara. Mempunyai pemahaman diri yang baik, dapat memahami apa yang menjadi kekurangan dan kelebihan diri masing-masing, ketiga informan juga mengerti apa yang mereka rasakan saat berada di dalam Lapas, namun informan kedua terkadang mempunyai pandangan negatif terhadap dirinya. Adanya gangguan pemahaman tentang diri sendiri ini cenderung berkembang sebagai individu yang tidak dapat menghargai dirinya sendiri. Individu yang dapat menerima diri akan memiliki harapan yang sesuai dengan kemampuannya termasuk mengetahui kelebihan dan kekurangan yang ada pada dirinya, sehingga individu tidak merasakan kecemasan terhadap masa depannya kelak. Warga binaan pemasyarakatan dengan penerimaan diri yang rendah seperti pada informan kedua merasakan kecemasan karena tidak mampu berpikir jernih bagaimana menghadapi masa depan. Warga binaan pemasyarakatan yang dapat menerima diri secara apa adanya tidak akan mengulangi kesalahan yang sama yang dapat merugikan diri sendiri dan orang lain. Oleh karena itu informan kedua sering meminta nasehat kepada pembimbing rohani saat program asimilasi berlangsung.

Warga binaan pemasyarakatan di lembaga pemasyarakatan dibimbing dengan diberikan pembinaan dalam segala kekurangannya. Situasi pemasyarakatan dibentuk menjadi situasi yang identik dengan situasi kekeluargaan. Situasi ini harus memiliki sifat peace (kedamaian), dan security 
(keamanan). Adanya peace dan security ini merupakan pendorong yang kuat terhadap terbentuknya eksplorasi dan penurunan kecemasan yang terjadi pada warga binaan pemasyarakatan. Diharapkan setelah selesai mengikuti pembinaan rohani dan selesai menjalani masa pidana, mereka memiliki kemampuan dalam menyesuaikan diri dengan kehidupan di luar Lembaga Pemasyarakatan sebagai Warga Negara yang baik, taat pada hukum yang berlaku. Sistem pembinaan yang dilakukan Lapas Wanita Kelas IIA Tangerang menurut Leli salah satu staf petugas Lapas bidang bimbingan rohani bahwa mereka telah berupaya menggunakan sistem melayani dan kekeluargaan kepada para warga binaan di Lapas Tangerang.

Ditambahkan oleh Leli bahwa mereka sebagai petugas menyadari bilamana individu dapat menerima dirinya, maka individu tersebut juga akan dapat menerima orang lain termasuk kekurangannya atau hal-hal positif dari orang lain. Individu tidak akan merasa minder dengan apa yang dimiliki, tidak terlalu silau dengan kelebihan orang lain, serta lebih fokus dalam usaha pengoptimalisasian potensi diri untuk mencapai kesuksesan. Penerimaan diri pada warga binaan pemasyarakatan wanita kasus narkoba di Lapas Wanita Kelas II A Tangerang akan mampu menjadikannya memahami status sebagai warga binaan pemasyarakatan yang dapat membuatnya dipandang secara berbeda oleh masyarakat, sehingga tidak merasa rendah diri ketika berada di lingkungan sosial yang mendorong munculnya kecemasan.

Penerimaan diri berarti seseorang harus membuka hatinya untuk bersedia menerima keseluruhan dirinya secara utuh dan tulus, termasuk kelebihan dan kekurangannya (Kuang, 2010). Penerimaan diri para informan menjadikan mereka dapat menerima status sebagai warga binaan pemasyarakatan dan berusaha untuk memperbaiki diri. Menerima keadaan bagi ketiga informan bukan berarti mereka hanya pasrah berdiam diri pada keadaan, melainkan berusaha bahwa menerima keadaan harus bisa bertahan menjalani masa hukuman hingga dapat potongan masa tahanan dan akhirnya bebas. Sehingga warga binaan pemasyarakatan wanita kasus narkoba kelak dapat hidup berdampingan dengan dengan masyarakat di sekitarnya tanpa rasa malu atau cemas akan mendapatkan penolakan dari masyarakat.

Para informan mengekspresikan kesadaran menerima kondisi mereka menjalani masa hukuman ditunjukkan dengan ketekunan mengikuti berbagai kegiatan atau program wajib dari Lapas, karena menurut Cici setiap kegiatan yang dilaksanakan ada absen kehadiran. Absensi kehadiran mengikuti kegiatan yang diadakan Lapas menjadi syarat warga binaan bisa mendapat 
potongan tahanan atau remisi dan mengikuti program asimilasi (persiapan warga binaan sebelum bebas). ${ }^{20}$

Masa Pidana (Asimilasi) merupakan suatu proses pembinaan terhadap narapidana yang dilaksanakan dengan membaurkan narapidana di dalam kehidupan masyarakat (berada di luar tembok). Salah satu syarat untuk mengikuti kegiatan asimilasi ini adalah apabila narapidana telah menjalani $1 / 2$ dari masa pidananya, setelah dikurangi masa tahanan dan remisi dihitung sejak putusan pengadilan memperoleh kekuatan hukum tetap. Tahap Akhir $\pm 2 / 3$ Masa Pidana bebas ( Masa Integrasi ) merupakan jika proses pembinaan telah menjalani 2/3 dari masa pidananya menurut tim pengawas pemasyarakatan (TPP) narapidana yang bersangkutan dinilai relatif siap untuk diterjunkan lagi di masyarakat, dengan tujuan (1) Tidak melanggar hukum lagi (2) Dapat berpartisipasi aktif dan positif dalam pembangunan manusia mandiri (3) Hidup berbahagia dunia atau akhirat (4) Membangun manusia mandiri, maka narapidana tersebut dapat diusulkan pembebasan bersyarat dan cuti menjelang bebas. Pada tahap ini keseluruhan program pembinaan dilakukan sepenuhnya di luar Lembaga Pemasyarakatan, Pengakhiran pembinaan dan bimbingan dari Lapas berdasarkan (a) Lepas mutlak karena telah habis masa pidananya (b) Pembebasan bersyarat karena telah melampaui $2 / 3$ dari masa pidana dan telah memenuhi persyaratan (c) Cuti menjelang bebas karena telah menjalani 2/3 masa pidananya menjelang lepas tetapi karena kesulitan teknis tidak dapat diberikan pembebasan bersyarat (d) Meninggal dunia dan kadaluarsa.

Kegiatan-kegiatan yang diberikan dalam rangka pembinaan merupakan kegiatan bermanfaat yang dapat berguna bagi narapidana kelak, meskipun jenis kegiatan yang diberikan masih terbatas ragamnya. Keterbatasan ragam kegiatan tersebut berkaitan dengan jumlah narapidana yang ada di Lapas Kelas II.A Tangerang. Kegiatan yang ada di Lapas Kelas II.A Tangerang tergantung pada tahapan masa pidananya. Pada awal 1/3 masa pidana kegiatan pembinaan yang dilakukan antara lain: (a) Pembinaan kesadaran beragama, (b) Pembinaan kesadaran berbangsa dan bernegara, (c) Pembinaan kemampuan intelektual, (d) Pembinaan kesadaran hukum. Pada tahap lanjutan yaitu 1/3-1/2 masa pidana diadakan kegiatan-kegiatan pembinaan seperti keterampilan untuk mendukung usaha-usaha mandiri misalnya menjahit dan memasak. Jadi pelaksanaan pembinaan kegiatan keterampilan yang diberikan kepada warga binaan di Lapas Klas II.A Tangerang memang jenisnya beragam dan pembinaan kegiatan keterampilan ini sangat bermanfaat bagi pelatihan kemandirian narapidana setelah keluar dari penjara untuk memulai kehidupan baru di masyarakat.

\footnotetext{
${ }^{20}$ Hasil wawancara dengan Cici (September 2019 Jumat pecan ke-2).
} 
Berdasarkan pembahasan di atas, pelaksanaan pembinaan terhadap narapidana wanita di Lapas Kelas II.A Tangerang menunjukkan bahwa sistem pelaksanaan dan mekanisme yang telah digunakan dalam pembinaan narapidana wanita di Lapas Kelas II.A Tangerang baik berupa pembinaan mental spiritual maupun pembinaan jasmani telah diberikan melalui programprogram kegiatan mulai dari pendidikan, keterampilan, kerohanian, keolahragaan dan kesenian sesuai dengan ketentuan dalam Undang-undang No. 12 tahun 1995 tentang Pemasyarakatan.

Dalam konsep pembinaan terhadap warga binaan wanita di Lapas yang menjadi bagian dari tujuan petugas erat kaitannya dengan keberhasilan pengembalian warga binaan ke masyarakat, dengan demikian bentuk pola pembinaan yang diberikan terhadap warga binaan besar pengaruhnya terhadap keberhasilan maupun kegagalan pengembalian warga binaan ke masyarakat. Untuk mencapai keberhasilan pembinaan tidak jarang ditemui beberapa hambatan dalam memberikan pembinaan di Lapas, hambatan persoalan yang ditemukan di Lapas berarti pula hambatan yang menyertai warga binaan nantinya setelah mendapatkan kebebasan. Berdasarkan hasil wawancara dengan Leli diketahui bahwa sebenarnya selama ini tidak ada masalah serius dalam pembinaan narapidana hanya kapasitas overload ada di Lapas Kelas IIA Tangerang, idealnya kapasitas Lapas menampung 250 warga binaan namun realitasnya di pertengahan 2019 berjumlah 406 orang. Hambatan lain yaitu terindikasi sedikit warga binaan memiliki kecenderungan perilaku seks menyimpang (lesbi) namun belum ada yang tertangkap langsung. Hambatan-hambatan tersebut tidak membuat petugas Lapas menyerah dan putus asa dalam menyelenggarakan kegiatan pembinaan rohani kepada warga binaan. Karena kegiatan pembinaan tetap dilaksanakan semaksimal mungkin untuk mencapai tujuan pembinaan dan agar dapat berguna bagi warga binaan serta dapat menjadi bekal ketika kembali ke dalam kehidupan masyarakat.

Diadakannya pembinaan agama bagi para warga binaan yang belum pandai sholat menjadi pandai dan paham tentang sholat yang baik dan benar. Bagi narapidana yang tidak pandai mengaji diajarkan cara mengaji mulai dasar hingga mahir tentang tajwid sehingga bisa membaca Al-qur'an dengan baik. Namun realitasnya belum mayoritas warga binaan mencapai tingkat pemahaman dan kemahiran membaca Al-qur'an karena seperti di awal disampaikan pada uraian sub bab sebelumnya, bagi warga binaan berubah sikap dan perilaku tidaklah mudah, dengan latar belakang gelapnya kehidupan mereka sebelumnya dan tidak paham agama membuat mereka sulit berubah. Para warga binaan senang bila mereka menemukan pembimbing rohani yang komunikatif dan memiliki kemampuan komunikasi yang dapat menstimuli mereka semangat mempelajari agama. Mereka merasa malas bila pembimbing rohani adalah figur yang memiliki gaya komunikasi membosankan. 
Wanita sebagai tiang Negara merupakan kelompok dalam masyarakat yang juga wajib mendapat jaminan perlindungan atas hak-hak yang dimilikinya secara asasi. Negara juga memiliki tanggung jawab untuk menjamin perlindungan hak asasi manusia kelompok wanita sama seperti jaminan kepada kelompok lainnya. (Niken Savitri, 2008:2). Pembinaan warga binaan wanita menurut agama Islam merupakan hal fundamental dalam kehidupan manusia, karena agama adalah jalan keselamatan bagi setiap umatnya. Dengan adanya pengajaran atau pendidikan keagamaan yang ditanamkan dalam kehidupan warga binaan, diharapkan akan lebih sadar tentang kesalahan-kesalahan yang dilakuakannya dan tidak mengulangi perbuatan kejahatan masa lalu. Namun pada kenyataanya, saat ini masih banyak warga binaan menjalani hukuman di Lapas Klas IIA Tangerang bahkan ada yang dua kali masuk penjara tersebut untuk kasus yang sama yaitu penyalahgunaan narkoba.

Pembinaan kepada warga binaan dilakasanakan bertujuan Islam membuat jera pelaku tindak pidana. Di dalam Agama Islam secara tegas diatur bahwa setiap orang yang melakukan kejahatan akan dihukum seperti dalam kasus pencurian seperti dipotong tangannya. Namun di negara Indonesia belum menemukan hukum Islam, namun sistem yang diterapkan yaitu melakukan pembinaan secara agama melalui lembaga pemasyarakatan agar warga binaan saat bebas nanti tidak melakukan kejahatan lagi. Selain itu, ada beberapa hal yang menjadi tujuan lain dilakukannya pembinaan warga binaan yaitu: (1) Memelihara Agama (Hifzh Al-din) (2) Memelihara Jiwa (Hifzh Al-Nafs) (3) Memelihara Akal (Hifzh Al-'Alql) (4) Memelihara Keturunan (Hifzh Al-Nasl) (5) Memelihara Harta (Hifzh Al-Mal) Dalam hukum Islam dijelaskan, bagi mereka yang telah di pidana ada sistem pemidanaanya seperti yang diungkapkan dalam surat Al-Maidah ayat 38 yang artinya: Laki-laki yang mencuri dan perempuan yang mencuri, potonglah tangan keduanya (sebagai) pembalasan bagi apa yang mereka kerjakan dan sebagai siksaan dari Allah dan Allah Maha Perkasa lagi Maha Bijaksana.

Ayat tersebut di atas menggambarkan adanya balasan terhadap sebuah kejahatan dan ketika membalas harus diumumkan atau dilakukan di muka umum, dengan demikian dapat disimpulkan bahwa berdasarkan tujuan pemidanaan adalah; Pertama, pidana dimaksudkan sebagai retribution (pembalasan), artinya setiap perbuatan yang melanggar hukum harus dikenakan sanksi sesuai dengan ketentuan Nas. Jangka panjang dari aspek ini adalah pemberian perlindungan terhadap masyarakat luas (social defence). Contohnya dalam hal hukum qisas yang merupakan bentuk keadilan tertinggi, dan di dalamnya termuat keseimbangan antara dosa dan hukuman. Kedua, pemidanaan dimaksudkan sebagai pencegahan kolektif (generale prevention), yang berarti pemidanaan bisa memberikan pelajaran bagi orang lain untuk tidak melakukan kejahatan serupa. Contohnya orang berzina harus didera di muka umum sehingga orang yang 
melihat diharapkan tidak melakukan perzinaan. Ketiga, pemidanaan dimaksudkan sebagai speciale prevention (pencegahan khusus), artinya seseorang yang melakukan tindak pidana setelah diterapkan sanksi ia akan bertaubat dan tidak melakukan kejahatan lagi. (Makhrus Munajat, 2001:66).

\section{KESIMPULAN}

Dari uraian hasil penelitian dan pembahasan hasil penelitian dapat diambil kesimpulan dan saran sebagaimana diuraikan berikut ini:

1. Penerimaan diri warga binaan wanita Lembaga Pemasyarakatan Wanita Kelas IIA Tangerang dalam menjalani masa tahanan mengalami pasang surut, namun semakin lama warga binaan mengikuti pencerahan melalui program asimilasi, warga binaan merasakan ada manfaat yaitu proses penerimaan diri semakin menguat dan keinginan mendekatkan diri pada Sang Khalik meningkat.

2. Penerimaan diri warga binaan wanita Lembaga Pemasyarakatan Wanita Kelas IIA Tangerang dalam menjalani masa tahanan pasca memperoleh pencerahan rohani agama Islam secara rutin dari Tim Relawan Da'wah Muslimat Dewan Da'wah Islamiyah Indonesia sebagai salah satu bagian dari program membentuk mental positif warga binaan melalui program asimilasi dirasakan sebagian peserta program asimilasi mempengaruhi pemahaman Agama Islam mereka makin besar terutama warga binaan makin mengenal Allah Ta'aala sebagai pencipta, tempat meminta dan mengadukan berbagai keluhan hidupnya. Warga binaan juga merasa makin kuat secara mental, tenag dan pasrah menjalani proses tahanan hingga selesai. Warga binaan merasa ada harapan pengurangan hukuman dengan perilaku yang baik.

\section{DAFTAR PUSTAKA}

Chaplin. J.P. 2005, Kamus Lengkap Psikologi, Jakarta, Raja Grafindo Persada. Hal.250

Dariyo, Agoes. 2007. Psikologi Perkembangan anak usia tiga tabun pertama ,Jakarta; PT Refika Aditama. Hal. 205

Dedy N. Hidayat. 2003. Paradigma dan Metodologi Penelitian Sosial Empirik Klasik, Jakarta : Departemen Ilmu Komunikasi FISIP Universitas Indonesia.

Effendy, Onong Uchjana. 2008. Ilmu Komunikasi, Teori \& Praktik.Bandung : PT. Remaja Rosdakarya 
Hurlock. E. Adolescent Development, (4 $4^{\text {th }}$ ed.) (Internal Student Edition). 1979.Hal.434

Hurlock, E. (1978). Personalitydevelopment. Tokyo: McGraw-Hill Publishing Company, Ltd.

Herdiansyah, H. (2012). Metodologi Penelitian Kualitatif untuk IlmuIlmu Sosial. Jakarta: Salemba Humanika.

H.B. Sutopo (2006). Metodologi Penelitian Kualitatif : Dasar teori dan Terapannya dalam Penelitian Surakarta: Universitas Sebelas Maret.

Milles, M.B. and Huberman, M.A. 1984. Qualitative Data Analysis. London: Sage Publication.

Muhammad Nazir, 1988, Metode Penelitian, Ghalia Indonesia, Jakarta.

Soelarko. 2015. Foto yang Berkisah. Semarang : Dahara Publishing.

Sunarjo dan Djonaesih S. Sunarjo.1983.Komunikasi Persuasif dan Retorika.Yogyakarta : Liberty

Saputra, Wahidin. 2011. Pengantar Ilmu Dakwah. Jakarta: PT. RajaGrafindo Persada.

Widjaja, A.W.1986. Komunikasi Komunikasi dan Hubungan Masyarakat.Jakarta : Bumi Aksara

Sumber lain:

Jurnal:

Intuisi Jurnal Psikologi, Kusumaningsih (2017), Penerimaan diri dan kecemasan terhadap status narapinada, http://journal.unnes.ac.id/nju/index.php/INTUISI.

Psikologika, Badaria, H; Astuti, YD. 2004.Religiusitas dan Penerimaan Diri pada Penderita Diabetes Mellitus.Psikologika Nomor 17 Tahun IX.

Ryff, C. D. 1989. Psychological WeilBeing in Adult Life. Journal of Psychological Science, Vol. 4, No. 4 (Aug., 1995), pp. 99-104

Ryff, C. D. (1989). Happiness is everything, or is it? exploration on the meaning of Psychological Well-being. Journal of Personality and SocialPsychology, 57, 6, 1069 - 1081

Skripsi/Thesis:

Rhenaldi Ardian Putra (2014), Universitas Muhammadiyah Surakarta: Hubungan antara Penerimaan Diri dengan Penyesuaian Diri pada Remaja Difabel.

Dian Apriliana (2009) Penerimaan Diri Narapidana ditinjau dari Kepribadian Tahan Banting.Skripsi thesis, Universitas Muhammadiyah Surakarta.

Lestariningsih, Thesis (2008). Hubungan antara kestabilan emosi dengan penerimaan diri pada narapidana wanita. Skripsi: Fakultas Psikologi Universitas Muhammadiyah Surakarta. 